\title{
Study on soil and water conservation regionalization in Changji Prefecture
}

\author{
Xiaozhuang Zhang ${ }^{1}$, Yajun Gao ${ }^{2 *}$ \\ ${ }^{1}$ College of Conservancy Engineering,Zhengzhou University, 450001,Zhengzhou, Henan, China;Tel:18203662619(Xiaozhuang Zhang) \\ 2 Yellow River Institute of Hydrology and Water Resources, Hydrographic Bureau of Yellow River Conservancy Commission, \\ 450003,Zhengzhou, Henan, China
}

\begin{abstract}
Taking once during as the study area, the course by using the DPSIR model and a lot of literatures screening of high frequency index, and quantitative analysis combined with the expert appraisal method, on once during regionalization index system establishment, course planning method was studied, determining the topographical features, water loss and soil erosion prevention and control system, land exploitation and utilization of direction, after years of average rainfall, population density, coverage of trees, soil and water loss area total area percentage as indicators of dividing the partition of soil and water conservation, such as in the villages and towns as the basic unit. Through principal component analysis, cluster analysis, the GIS space superposition method for regionalization, will once during divided into course will once during is divided into six course four areas: the southern mountain freeze-thaw district, Zhongshan in southern hilly water conservation ecological reserve, with low hills in southern soil conservation area, central oasis environment farmland protection area in northern desert ecological maintenance, low mountain in northern wind sand area, ecological maintenance area 6 level 4 area of water conservation, determine the various functional areas of soil erosion prevention and control of system layout, the direction of land use, for once during planning of soil and water conservation and soil erosion prevention and control system of the course layout provides the scientific basis.
\end{abstract}

\section{Overview of the research area}

Changji Hui Autonomous Prefecture (hereinafter referred to as "Changji Prefecture") is one of the administrative regions under the jurisdiction of the Xinjiang Uygur Autonomous Region.Is located in tianshan mountain, the southeast margin of junggar basin, with east, Shihezi city west, south and Turpan city, general Mongolian autonomous prefecture of adjacent, north border with Tuscaloosa, Altay region, the northeast border with Mongolia, border $227.3 \mathrm{~km}$, is a new north road, the ancient "silk road" to the path to the countries of central Asia and Europe. Geographical coordinates between east longitude $85^{\circ} 17$ '50 "15" $91^{\circ} 32^{\prime}$, north latitude $43^{\circ} 31^{\prime} 06^{\prime} \sim 45^{\circ} 38^{\prime} 50$ ", a state of things is $541 \mathrm{~km}$ long, north and south 285 kilometers wide, land area of $73485 \mathrm{~km} 2$, during is course construction is an important part of the silk road of Xinjiang economic belt core, and Urumqi-Changji stone city in the Northern Slope economic zone is take the lead in the development of the core area, from something north surrounded on three sides of Urumqi, with the development of integration in Urumqi city location advantage, state Changji is $35 \mathrm{~km}$ away from Urumqi city center, $18 \mathrm{~km}$ away from Urumqi International Airport. The Northern Xinjiang Railway, 312 National Highway, 216 national Highway, 115 provincial highway and Tu-Wu-Da highway run through the whole territory, serving as a bridgehead and golden passage connecting the eastern China and the central Asian and European markets in the west. The terrain of Changji Autonomous Prefecture is high in the south and low in the north, and slopes from the southeast to the northwest, with the Tianshan mountains in the south, the vast alluvial plain in the middle and the vast desert basin in the north. This area is the Northern Slope of The Tianshan Mountains stretching across the south, which is commonly known as the "Northern Slope of Tianshan Mountains". Changji city belongs to the temperate zone and has a typical continental arid climate, characterized by cold winter, hot summer and large temperature difference between day and night. Due to the influence of topographic conditions, there is a great difference in climate from south to north, and there is more precipitation in summer in the south. The desert climate in the north is remarkable. The sunshine in Changji Prefecture is abundant, with 2700 hours of sunshine per year. The annual cumulative temperature $\geq 10^{\circ} \mathrm{C}$ is $3450^{\circ} \mathrm{C}$, and the annual average temperature is $6.8^{\circ} \mathrm{C}$. The average temperature in January is $-15.6^{\circ} \mathrm{C}$, and the average temperature in July is $24.5^{\circ} \mathrm{C}$. The average annual precipitation is $190 \mathrm{~mm}$, and the precipitation in summer is significantly higher than that in winter. The annual frost-free period is 160-190 days. 
The soil erosion types in Changji prefecture are complex and diverse, which can be divided into wind erosion, hydraulic erosion and other main types. Wind erosion is the most important and typical type of erosion in Changji Prefecture. Although hydraulic erosion has a small area, it is highly destructive and has a large influence area. It is also one of the main forms of soil erosion in Changji Prefecture. The soil erosion area of the study area is $46,300 \mathrm{~km} 2$, accounting for $5.2 \%$ (4.63/88.54) of the soil erosion area of Xinjiang, and $63.0 \%(4.63 / 7.35)$ of the territorial land of the whole prefecture, among which the hydraulic erosion area is $4,300 \mathrm{~km} 2$ and the wind erosion area is 42,000 $\mathrm{km} 2$.According to the grade of soil erosion intensity, the areas of mild, moderate, intense, extreme and violent erosion are 26,900 km2, 710,000 km2, 74,400 km2, $39,900 \mathrm{~km} 2$ and 100,000 km2, respectively, accounting for $58.16 \%, 15.29 \%, 15.95 \%, 8.42 \%$ and $2.19 \%$ of the total soil erosion area, among which the proportion of mild erosion area is the largest, reaching $58.16 \%$.Soil erosion is a serious threat to the living environment of local people.

\section{Index selection method regionalization method}

and

By reading a large number of soil and water conservation districts literature, most of these studies are some indicators of regional soil and water loss is analyzed, and does not take into account different indicators relate to each other and influence each other, the question of causality as the social economy and environment, caused by human activities and environmental status of the feedback effect of the society, cannot reflect the various aspects of different factors, therefore, the selection of index for soil and water loss can only have a vague guidance, is not specific to every aspect of society, economy and nature. Based on this, this paper puts forward a method of selecting soil erosion index by DPSIR model. Based on DPSIR model can be more comprehensive analysis of the related factors of soil erosion, more scientific to select indicators for soil and water loss, high frequency division indexes, a lot of literatures and tertiary thinning area zoning index, based on the DPSIR model, selection of high frequency index, level 3 area after refining division index, and then take the expert evaluation method, the topographical features, grass coverage, years of average rainfall, soil erosion type and thinning intensity, population density, In addition, the percentage of soil and water loss in the total area, the soil loss control system, the direction of land development and utilization, and the thickness of soil layer are the regionalization indexes of Changji Prefecture.

The principal component analysis (PCA) with the function of dimensionality reduction and aggregation combined with system clustering and GIS spatial superposition were used to determine the results of regionalization according to the principle of centralized concatenation and regional conjugation

\section{Data Sources}

To avoid the interannual fluctuation of data and the error of data statistics, so that the characteristics is more representative, this article are based on the original data from 2003-2018 ".During water course bulletin" and "Changji hui autonomous prefecture, statistical yearbook (Changji hui autonomous prefecture, statistics bureau, 2018)," .During the social and economic statistical yearbook course, China's economic and social development statistical database, etc., including literature data access, etc. At the same time because of too many indicators, makes analysis of the complexity of the increase, so the dimension reduction function and the polymerization of the combination of principal component analysis and system clustering method.

\section{Zoning results}

At once, during the four area, six pieces of course based on the spatial pattern of soil and water loss prevention, according to the national soil and water conservation districts guidelines (trial) ", this division USES 4 class partition system, primary area for the overall pattern of area, the secondary area for regional coordination area, level 3 area as the basic function, level 4 area (state level partition) as the partition of soil and water conservation.

In the national soil and water conservation zoning, Changji Prefecture is located in the northern sandstorm area level I subdivision, the northern Xinjiang mountain basin area level II subdivision, the North Slope of Tianshan Mountain habitat environment farmland protection area level III.

In accordance with the requirements of the overall direction, the soil and water conservation contents related to natural forest protection, grassland protection construction, land consolidation, desert management and overall urban and rural development shall be comprehensively coordinated, and on the basis of soil and water conservation regionalization, the first-level zoning layout of soil and water conservation in Changji Prefecture shall be formulated. For ease of reflecting the different regional location and the characteristics of soil and water loss and soil erosion prevention and control of the direction. During area is divided into six level course: Zhongshan south mountain freeze-thaw zones, ecological protection areas, with low hills in southern hilly water conservation soil conservation area, central oasis environment farmland protection area in northern desert ecological maintenance of wind sand area, water conservation ecological maintenance, low mountain in northern area.

Table 1.Results of soil and water conservation zoning in Changji Prefecture

Level 3 area $\begin{gathered}\text { State - level division } \\ \text { name }\end{gathered} \quad$ Area $\left(\mathbf{k m}^{2}\right)$




\begin{tabular}{|c|c|c|}
\hline \multirow{6}{*}{$\begin{array}{l}\text { Tianshan } \\
\text { North Slope } \\
\text { living } \\
\text { environment } \\
\text { farmland } \\
\text { protection } \\
\text { area }\end{array}$} & $\begin{array}{l}\text { Alpine freeze-thaw zone } \\
\text { in the south }\end{array}$ & 3507 \\
\hline & $\begin{array}{l}\text { South Zhongshan Hill } \\
\text { Water conservation } \\
\text { ecological protection } \\
\text { zone }\end{array}$ & 9071 \\
\hline & $\begin{array}{c}\text { Southern low mountain } \\
\text { foothill soil retention } \\
\text { area }\end{array}$ & 8865 \\
\hline & $\begin{array}{l}\text { Central oasis habitat } \\
\text { environment farmland } \\
\text { protection area }\end{array}$ & 18472 \\
\hline & $\begin{array}{c}\text { Northern desert } \\
\text { ecological maintenance } \\
\text { windbreak sand control } \\
\text { area }\end{array}$ & 30111 \\
\hline & $\begin{array}{c}\text { North, low mountain } \\
\text { water conservation and } \\
\text { ecological conservation } \\
\text { area }\end{array}$ & 3459 \\
\hline
\end{tabular}

\subsection{Layout of regional prevention and control system}

The southern part of Changji prefecture is a mountainous area in the north slope of Tianshan Mountain, which accounts for about $20 \%$ of the land area of the whole prefecture and is the main tourist landscape belt of Changji Prefecture.The beautiful Jiangbulake scenic spot, the majestic Bogda Peak (5445m), the picturesque alpine lake Tianchi, the mysterious Kangiia Shi-gate rock painting, the mysterious Fenghuang Mountain scenic spot and other high quality tourist attractions are located in this area. This part of the tourism area is mostly prohibited from development, so special attention should be paid to environmental issues in the development process. Scenic spots need to set up core area, buffer zone and tourist area, the core area is forbidden to tourists, is the key protection area of the ecological environment, scenic area development is mainly concentrated in the tourist area.

\subsubsection{Southern alpine freezing-thawing area}

This area is located at the top of the Tianshan Mountain in the south, the high mountain area is covered with snow all the year round, there are a lot of modern glaciers, the altitude is about $3000-5445 \mathrm{~m}$, from the west to the east there are roughly parallel To the IranHabiergat Mountain, Tiangeer Mountain, Bogda Mountain composition, is the main source of the river in the area. Freezing-thawing erosion is dominant in this area. This area is far away from residential areas and all located within the national prevention zone. It should be sealed off and protected to reduce human interference.

\subsubsection{South Zhongshan Hill Water Conservation Ecological Protection Zone}

This area is the Tianshan Mountain in the south, with undulations in the Zhongshan belt. Within the range of $1150-3000 \mathrm{~m}$ above sea level, the vertical zone of mountain vegetation is relatively complete, the mountain is precipitous, the maximum height difference is over 100 meters, the mountain area is cut strongly, and the valley is developed. Its natural characteristics are abundant rainfall, fertile soil, rich water and grass, dense virgin forests, rich in various plants and animals and mineral resources. Moderate hydraulic, mild wind and gravity combined erosion are dominant in this area.

Problems: Grassland overgrazing, grass quantity decreased, grass quality deteriorated; Artificial soil erosion caused by tourism, water conservancy projects, mining and other development and construction projects has not been effectively controlled.

\subsubsection{Southern low mountain and hilly soil conservation area}

The southern hilly region is flat and belongs to the original denudation tectonic landform. In the low hills and hills with an altitude of $950-1150 \mathrm{~m}$, the thick tertiary strata are mostly exposed. Due to the scouring action of rivers and floods, the topography is crisscross with gullies and terraces developed on both sides of the valleys. Every year from winter to autumn, snow cover and glacial meltwater in high mountain areas combine with seasonal snowmelt water, rainfall and rainstorm in low mountain areas to provide water for rivers and become runoff forming areas of rivers. The intensity of hydraulic and moderate wind erosion is dominant in this area.

\subsubsection{Farmland Protection zone of central Oasis human settlement environment}

The central area of Changii prefecture is the piedmont plain area at the northern foot of Tianshan Mountain, which accounts for about $25 \%$ of the total land area of the prefecture. This region is the main agricultural area, but also Changji prefecture politics, economy, culture more developed region. Since ancient times, it has been an important place for people of all ethnic groups to develop agriculture and animal husbandry, and to live and reproduce. Historical sites and scenic spots left by various social and economic activities are very common. At the same time, it has formed a recreational belt around the city with large and medium-sized cities as the center and urban residents' needs as the core. This area belongs to the restricted development area. Although it also belongs to the ecologically fragile area, compared with the natural ecological area in the south, it is more suitable for tourism development. Tourism can be combined with the construction of agriculture, culture and characteristic towns to create characteristic tourism towns.

The farmland protection area in the central part of the living environment is an alluvial and alluvial inclined plain and fine soil plain area formed by the diluvial and alluvial action of various rivers. The topography here is 
undulating, and the terrain slopes from southeast to northwest, with lacustrine deposition distribution in some parts. The elevation is $400 \sim 1000 \mathrm{~m}$, and the topographic gradient is $1 \% \sim 15 \%$. On the alluvial and alluvial fans, the scouches with a depth of $2 \sim 10 \mathrm{~m}$ are formed on the fan surface due to the erosion and cutting action of running water. The alluvial plain area is flat, and due to the erosion of running water, pinniform and branchlike gullies are developed with a depth of $3 \sim 5 \mathrm{~m}$. In some areas, due to the flood or the exposure of groundwater, there are puddles and reeds growing. The area is the core of human life and production activities, as well as an important production base of petroleum, chemical industry, agriculture, forestry and animal husbandry in Xinjiang. Oases form wherever rivers go. Most of the river runoff from the mountains is used up in the oasis, and only a few rivers have rain water into the desert. Therefore, this area is the utilization and loss area of river runoff. Moderate wind force and slight hydraulic erosion are dominant in this area.

\subsubsection{Northern desert ecological maintenance windbreak and sand control area}

The northern part of Changji Prefecture is mostly covered by deserts, which are $400 \sim 600 \mathrm{~m}$ above sea level. This area has a dry climate and little rain. Rich deserts and sandy vegetation form different types of desert landscapes, which have become an important tourist resource in this area. General Temple, multicoloured Bay, silicified wood .All the national geoparks are in this area. From the perspective of resource quality, some of them belong to the unique resources in this area and have strong development value. However, this region also belongs to a region with extremely fragile ecological environment and is a prohibited development zone, so it needs to pay attention to environmental protection in the development process just like the southern natural ecological tourism zone.

It mainly refers to the Gurbantungu Desert and The General Gobi Desert, with an altitude of 280 $1100 \mathrm{~m}$. The desert area is $280 \sim 850 \mathrm{~m}$ above sea level.

Problems: Lack of drinking water, poor combination of water and grass, weak disaster resistance of livestock, often affected by strong wind and low temperature; The exploitation of mineral resources will cause man-made disturbance, which will easily cause additional soil and water loss.

\subsubsection{North water conservation and Ecological Conservation area in middle and low Mountains}

This area refers to the mountains and hills to the north of the desert. The mountains are low and low, with an altitude of $800 \sim 3000 \mathrm{~m}$. They are mainly composed of North Tashan, large and small Hafutik Mountains and Kekse Mountains. The surface is mostly covered by weathering and semi-weathering, and rainfall is rare, with annual rainfall of $100 \sim 200 \mathrm{~mm}$. The vegetation coverage rate is low, except for larch scattered in the shade slope of Beita Mountain, most of the low xerophytic desert plants only grow in the mountain gully area. This area is the winter pasture of Mulei County, due to the lack of water, the pasture utilization rate is only $30 \%$.Moderate wind force and moderate hydraulic erosion dominated the area.

\section{References}

1. Hu J.B. (2018) Discussion on soil erosion and ecological management in Karst area of Guizhou Province. China Resources Comprehensive Utilization, 36(02):124-125+134.

2. Fu W.B.,Dai Q.H.,Yan YJ. (2015)The response of soil erosion in Karst slope and its shallow underground crevasse ratios. Journal of Soil and Water Conservation, 29(02):11 - 16+22.Yue K.Q. (2016)

3. Lu G.Y.,Li S.,Wei X.H., et al. (2013) The processes of soil degradation in Rock Desertification area of northern Guangdong. Journal of Soil and Water Conservation, 27(02):20-25.

4. Li Y, Bai X, Zhou Y, et al. (2016)Spatial-Temporal Evolution of Soil Erosion in a Typical Mountainous Karst Basin in SW China, Based on GIS and RUSLE.

5. Arabian Journal for Science and Engineering, 2016, 41(1):209-221.Chen G.Y.(2018)

6. M.A. Busari, S.S. Kukal, A. Kaur, R. Bhatt, A.A. D ulaziConservation tillage impacts on soil, crop and the environment Int Soil Water Conserv Res, 3 (2015),pp. 119129, 10.1016/j.iswcr.2015.05.0 02 